\title{
Alternations in salivary glucose during ramadan fasting
}

\author{
Reyhaneh Sariri $^{1 *}$, Abdolali Varasteh ${ }^{1}$, Ali Erfani ${ }^{2}$ \\ ${ }^{1}$ Department of Biochemistry, The University of Guilan, Rasht, Iran; *Corresponding Author: sariri@guilan.ac.ir \\ ${ }^{2}$ Department of Internal Medicine, Iran University of Medical Sciences, Tehran, Iran
}

Received. 21 October 2009; revised 7 December 2009; accepted 9 December 2009.

\begin{abstract}
During the holly month of Ramadan, Muslims fast every day from dawn to sunset. Although the effect of Ramadan fasting on general health has been widely studied, the impact of fasting on oral health and possible changes in salivary biochemicals, such as glucose, has not received much attentiom. The aim of our study was to evaluate the influence of fasting on the level of glucose in the saliva of healthy individuals. Salivary glucose was measured using an enzymatic method based on oxidation of glucose by glucoseoxidase followed by determination of resulting $\mathrm{H}_{2} \mathrm{O}_{2}$ in the presence of peroxidase. A reduction in mean concentration of glucose was observed in the saliva of all fasting subjects as compared to the control group. It was concluded that reduction in salivary glucose is mostly due to reduced food intake and may be beneficial to dental health.
\end{abstract}

Keywords: Saliva; Glucose Level; Diabetes; Fasting

\section{INTRODUCTION}

Several of the world's great religions recommend a period of fasting or abstinence from certain foods. Of these, the Islamic fast during the Muslim month of Ramadan is strictly observed every year. During the month of Ramadan, Muslims fast every day from dawn to sunset. Muslims observing the fast are required to abstain not only from eating and drinking, but also from consuming oral medications and intravenous nutritional fluids.

It has been found that, in the healthy subject, Ramadan fasting does not appreciably affect one's health. However, it may induce some complications in patients with important metabolic disorders such as diabetes. The effect of experimental short-term fasting on carbohydrate metabolism has been extensively studied [1,2].
Mean normal blood glucose levels in humans are about $90 \mathrm{mg} / \mathrm{dl}$, equivalent to $5 \mathrm{mM}(\mathrm{mmol} / \mathrm{l})$. It has been found that a slight decrease in serum glucose $600-70$ $\mathrm{mg} / \mathrm{dl}, 3.3-3.9 \mathrm{mM}$ ) occurs in normal adults a few hours after fasting has begun. However, the reduction in serum glucose ceases due to increased gluconeogenesis in the liver [3].

Saliva is the first biological fluid to encounter any change in eating habits as well as any environmental or physical changes. Saliva influences oral health both through its non-specific physico-chemical properties, as well as through more specific effects [4]. Saliva is well known for its highly protective functions against deterious agents such as microorganisms, toxines and various oxidants $[5,6]$. The antioxidant capacity and reducing power of saliva may diminish to a high degree due to various factors [7]. It has been shown that in vitro exposure to cigarette smoke could significantly decrease some enzymatic activities, both in plasma and in saliva $[8,9]$.

The research reports in this area are few and almost limited to the changes of glucose concentrations in plasma. This study reports alternations in glucose content of saliva during one month fasting in Ramadan 1428 (Sept. 22 ${ }^{\text {nd }}$-Oct $12^{\text {th }}$ 2007).

\section{MATERIALS AND METHODS}

\subsection{Materials}

The level of glucose in saliva was measured using an enzymatic method based on oxidation of glucose by glucoseoxidase followed by determination of resulting $\mathrm{H}_{2} \mathrm{O}_{2}$ in the presence of peroxidase. An enzymatic assay glucose kit was purchased from Pars Azmoon ${ }^{\mathrm{TM}}$. The kit consisted of a standard glucose and a colour reagent. The concentration of standard glucose was $100 \mathrm{mg} / \mathrm{dl}$ and the colour reagent was a mixture of the following chemicals: $250 \mathrm{mmol} / \mathrm{l}$ phosphate buffer $\mathrm{pH}$ 7.5, $5.0 \mathrm{mmol} / \mathrm{l}$ phenol, $0.5 \mathrm{mmol} / \mathrm{l}$ 4-aminoantipyrine $10 \mathrm{ku} / \mathrm{l}$ glucose oxidase and $1 \mathrm{ku} / \mathrm{l}$ peroxidase. 


\subsection{Volenteers}

30 healthy male students (mean age 24.21 years, $\mathrm{s}_{\mathrm{x}}=$ 2.34), who intended to fast the whole Ramadan. 30 samples for control and comparison were also collected from the same students who donated their saliva in the month before Ramadan when they performed normal eating pattern. A precise consent was obtained from each individual and a dentist examined their mouth and teeth before sample collection.

\subsection{Collection of Saliva Samples}

The subjects were examined by a dentist for the absence of infection and other symptoms of oral/and or dental disorders. A few volunteers with severe infections were excluded from the research. After gaggling their mouth with about $5.0 \mathrm{ml}$ of distilled water for about 2 minutes, timed un-stimulated whole saliva samples $(3 \mathrm{ml})$ were collected in clean, dry in sterile pre-weighted tubes. The duration of saliva sampling was altered among individuals depending on their flow rate (2.0-5.0 minutes). The flow rate was calculated by measuring the time required to collect one ml of saliva in minutes. During the holly month of Ramadan, saliva samples were donated mid-day (after about 6 hours fasting) and three samples collected from each volunteer during one month of Ramadan (days 1-9, 10-19 and 21-29). Three control samples from each volunteer were also collected at the same time of the day during a non-fasting period, i.e. one week after Ramadan. All of the saliva samples were immediately centrifuged at $800 \times \mathrm{g}$ for $10 \mathrm{~min}$ at $4^{\circ} \mathrm{C}$ to remove squamous cells and cell debris. The resulting supernatant was stored at $-18^{\circ} \mathrm{C}$ until used for determination glucose content. They were analyzed within 48-72 hours of collection. Each assay was repeated three times and the data obtained were expressed as mean \pm SD of the three determinations. To test the effect of freezing on the glucose content of saliva, random measurements on fresh samples were also performed. No significant difference was observed between thawed and fresh samples. Therefore, only the frozen samples were used for continuing studies.

\subsection{Glucose Assay}

Glucose concentration was determined in supernatant of saliva samples collected from volunteers. The level of glucose in saliva was measured using an enzymatic method based on oxidation of glucose by glucose oxidase (GOD) followed by determination of resulting $\mathrm{H}_{2} \mathrm{O}_{2}$ in the presence of peroxidase (POD).

\section{Glucose $+\mathrm{O}_{2} \stackrel{\text { GOD }}{\longrightarrow}$ Gluconic acid $+\mathrm{H}_{2} \mathrm{O}_{2}$}

$2 \mathrm{H}_{2} \mathrm{O}_{2}+4$-Aminoantopyrine + Phenol POD $\longrightarrow$ Quinoneimini $+4 \mathrm{H}_{2} \mathrm{O}$
$1000 \mathrm{ml}$ of reagent was mixed with $30 \mathrm{ml}$ of each saliva sample. The mixture was incubated in a $37^{\circ} \mathrm{C}$ water bath and the intensity of resulting colour was measured spectrophotometrically at $546 \mathrm{~nm}$ against a blank of containing $1000 \mathrm{ml}$ reagent and $30 \mathrm{ml}$ distilled water.

Glucose concentration $\left(\mathrm{C}_{\mathrm{G}}\right)$ in whole saliva was calculated using the Beer-Lambert's equation and absorbances of standards solution $\left(A_{S}\right)$, each sample $\left(A_{T}\right)$ and concentration of standard $\left(\mathrm{C}_{S}\right)$.

$$
\mathrm{C}_{\mathrm{G}}(\mathrm{mg} / \mathrm{ml})=\mathrm{A}_{\mathrm{T}} / \mathrm{A}_{\mathrm{S}} \times \mathrm{C}_{\mathrm{S}}(100 \mathrm{mg} / 100 \mathrm{ml})
$$

\subsection{Statistics}

Each assay was repeated triplicate and the results were presented as mean \pm SD values. Statistical difference between groups was compared by un-paired t-test, $\mathrm{p}$ values less than 0.5 were retained as significant.

\section{RESULTS}

The saliva flow rate ranged from 0.08 to $1.40 \mathrm{ml} / \mathrm{min}$ at rest and showed about $10 \%$ decrease in response to fasting. Concentration of glucose was calculated in mg/100 $\mathrm{ml}$ using the absorbance and standard concentration. Figure 1 compares content of glucose in saliva of some selected volenteers during fasting and non-fasting period. The data presented in this figure are a random selection from saliva samples of 30 volenteers. It should be emphasized that the results of other samples were similar to the randomly selected ones. The mean values together with p values are shown in Table $\mathbf{1}$.

\section{DISCUSSION}

The effect of experimental short-term and Ramadan fasting on carbohydrate metabolism has been extensively

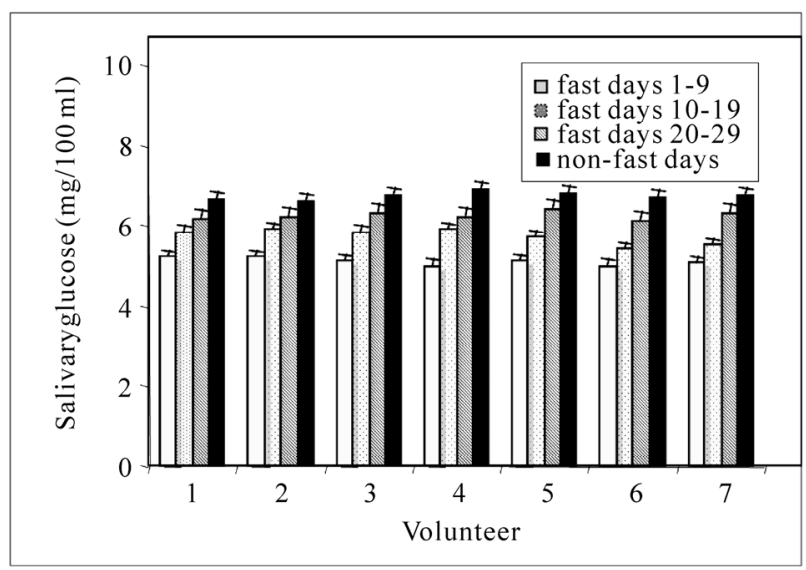

Figure 1. Comparison of glucose level in saliva samples of non-fast (control) with fasting group during different days of Ramada. 
Table 1. Mean \pm SD salivary glucose $(\mathrm{mg} / 100 \mathrm{ml})$ of subjects during fasting nad non-fasting period.

\begin{tabular}{lcc}
\hline Sample collected during & $\begin{array}{c}\text { Salivary glucose concen- } \\
\text { tration }(\mathrm{mg} / 100 \mathrm{ml})\end{array}$ & P values* \\
\hline First 10 days of Ramadan & $54.5 \pm 0.74$ & 0.5 \\
Second 10 days of Ramadan & $58.8 \pm 1.25$ & 0.6 \\
Third 10 days of Ramadan & $63.6 \pm 9.43$ & 0.5 \\
First week after Ramadan & $68.5 \pm 1.22$ & NS \\
\hline
\end{tabular}

Values presented as Mean \pm SD.

* P values were compared by t-test; NS - not significant

studied [10-13]. It has been found that a slight decrease in serum glucose to $60 \mathrm{mg} / \mathrm{dl}$ to $70 \mathrm{mg} / \mathrm{dl}$ occurs in normal adults a few hours after fasting has begun. However, the reduction in serum glucose ceases due to increased gluconeogenesis in the liver. In this study, some blood samples from the same subjects were also taken exactly the same day of saliva collection in order to compare the pattern of change in saliva and blood (results are not included in this report).

It can be seen from data given in Figure 1, that a mean $20-25 \%$ reduction in salivary glucose has occurred during the first 10 days of Ramadan fasting followed by a less reduction in the next ten days and, finally, another rise by the $29^{\text {th }}$ day of Ramadan fasting. Rise in salivary glucose during the last 10 days of Ramadan did not, however, reach the normal glucose level as compared to the non-fast volenteers. Examination of blood samples of each volenteer showed some similar alternations. However, the results need more investigations and, therefore, are not presented in this paper. There are only a few reports about blood glucose variations due to fasting during Ramadan $[12,13]$. In the case of blood glucose, reduction during the first 10 days of Ramadan could almost be compensated by the middle of the month due to gluconeogenesis. In saliva, however, maintenance of glucose concentration in low level compared to blood glucose, suggests that gluconeogensis provides glucose mostly for leveling the blood glucose. This is an interesting phenomema bearing in mind that the function of glucose in saliva is not as critical as it is in blood.

\section{CONCLUSIONS}

Normal salivary function is considered to be critical for the maintenance of healthy oral mucosa [4-6]. Oral fluids provide an easily available non-invasive for the diagnosis of a wide range of diseases and clinical situations. The effect of Ramadan fasting on some blood factors such as thyroid hormons $[14,15]$, plasma lipopro- teins [16], serum glucose and many other laboratory findings [11-13] have been reported. However, according to our literature survey, saliva has received less attention in this regard. The laboratory findings reported in this research, indicate that the glucose concentration in saliva is decreased during fasting, mainly at the beginning of the month.

It was shown that about $25 \pm 2 \%$ reduction in the first 10 days was followed by a rise $(17 \pm 2 \%$ reduction compared to the non-fasting state) in the next ten days and finally another rise in the last 10 days of the month. According to these results, it was concluded that although fasting during Ramadan affected salivary glucose concentration, it had no impact on the glucose function in saliva of healthy people. As concentration of glucose in saliva is highly dependent on the food intake and does not play a crucial role in carbohydrate metabolism [17, 18], we concluded that reduction in salivary glucose during fasting is not accompanied by serious health risks.

\section{REFERENCES}

[1] Cahill, G.F.Jr. (1970) Starvation in men. The New England Journal of Medicine, 282, 668-675.

[2] Herber, D. (1995) Endocrine response to starvation, malnutrition, and illness. In: DeGroot Ly, Ed., Endocrinology, 3rd Edition, Saunders, Philadelphia, 2663-2678.

[3] Azizi, F. (1996) Medical aspects of Islamic fasting. Iranian Journal of Medical Sciences, 10(1), 241-246.

[4] Dodds, M.W.J., Johnson, D.A. and Yeh, C.K. (2005) Health benefits of saliva. Journal of Dentistry, 33(3), 223-233.

[5] Lebanthal, E. (1987) Role of salivary amylase in gasteric and intestinal digestion of starch. Digestive Diseases and Sciences, 32(10), 1155-1157.

[6] Tabak, L.A., Levine, M.J., Mandel, I.D. and Elison, L.A. (1982) Role of salivary mucins in the protection of the oral cavity. Journal of Oral Pathology \& Medicine, 11(1), 1-7.

[7] Kohen, R., Tirosh, O. and Kopolovich, K. (1992) The reductive capacity index of saliva obtained from donors of various ages. Experimental Gerontology, 27(2), 161168.

[8] Nagler, R., Lischnisky, S., Diamond, E., et al. (2000) Effect of cigarette smoke on salivary proteins and enzyme activeties. Archives of Biochemistry and Biophysics, 379(2), 229-236.

[9] Zappacosta B., Persichilli S., Mordente, A., et al. (2002) Inhibition of salivary enzymes by cigarette smoke and protecttive role of glutathione. Human and Experimental Toxcology, 21(1), 7-11.

[10] Azizi, F. and Rasouli, H.A. (1987) Serum glucose, bilirubin, calcium, phosphorus, protein and albumin concentrations during Ramadan. Iranian Journal of Medical Sciences, 1, 38-41.

[11] Haouri, M., Haourai-Oukerro, F., Mebazaa, A. and Nagati, K. (1997) Circadian evolution of serum level of glucose, insulin, cortisol and total proteins in healthy, 
fasting volunteers. Second International Congress on Health and Ramadan, Istanbul.

[12] Scott, T.G. (1994) The effect of Muslim fast of Ramadan on routine laboratory investigation. Journal of King $A b$ dulaziz University, 1(4), 23-35.

[13] Bagraicik, N., Yumuk, V., Damei, T. and Ozyazar, M. (1992) The effect of fasting on blood glucose, fructosamine, insulin and C-peptide levels in Ramadan. First International Congress on Health and Ramadan, Casablanca, Morocco.

[14] Sajid, K.M., Akhtar, M. and Malik, G.Q. (1991) Ramadan fasting and thyroid hormone profile. Juvenile Products Manufacturers Association, 41(9), 213-216.

[15] Sulimani, R.A. (1988) Effect of Ramadan fasting on thyroid function in healthy male individuals. Nutrition Research, 8(5), 549-552.

[16] Shoukry, M.I. (1986) Effect of fasting in Ramadan on plasma lipoproteins and apoproteins. Saudi Medical Journal, 7(6), 561-567.

[17] Mayes, P.A. (2000) Digestion and absorption. Harpers, Biochemistry, In: Murray, R.K. Granner, D.K. Mayes, P.A. and Rodwell, V.W. Eds., 25th Edtion, Appleton and Lange, New York, 666-674.

[18] Negoro, M., et al. (2000) Oral glucose retention, saliva viscosity and flow rate in 5-year-old children. Archives of Oral Biology, 45(1), 1005-1011. 